\title{
副鼻腔に転移した腎癌例
}

\author{
大野 恒久・野々村光栄・菊川 達雄
}

\section{A Case of Renal Cell Carcinoma, Metastasized to the Paranasal Sinuses}

\author{
Tsunehisa Ohno, Mitsuharu Nonomura and Tatsuo Kikugawa \\ (Sizuoka City Hospital)
}

\begin{abstract}
We report a case of renal cell carcinoma that metastasized to the paranasal sinuses. A 78-year-old male who had had a left nephrectomy 5 months before under the diagnosis of renal cell carcinoma, complained of epistaxis, nasal obstruction and visual disturbance. A CTscan demonstrated a tumor in the nasal cavity and paranasal sinuses. An open biopsy revealed that the histopathologic diagnosis was metastatic renal clear cell carcinoma (grade 2) to the paranasal sinuses. We performed radiation therapy (50 Gy) to the paranasal sinuses as conservative treatment. Currently, the tumor in the paranasal sinuses seems to be growing gradually.
\end{abstract}

Key words : renal cell carcinoma, paranasal sinuses

はじめに

鼻・副鼻腔に他臓器からの転移性腫瘍が発生するのは 比較的まれである. 今回, われわれは腎細胞癌手術施行 5 力月後に鼻出血, 視力低下, 眼球突出をきたした副鼻空 転移例を経験したのでここに報告する.

\section{症例}

症例：78 歳, 男性.

主訴 : 右鼻出血, 鼻閉, 右視力低下.

既往歴：左腎摘出術（平成 12 年 5 月 12 日), 糖尿病, 心筋梗塞.

現病歴: 平成 12 年 10 月頃より右鼻出血, 鼻閉, 右視 力低下が出現. 他施設にて易出血性の副鼻腔腫瘍性病変 として加療されていた. また, 当院泌尿器科にて腎癌に 対する術後経過観察をされていたが，11月 21 日腎癌の 肺転移がみつかり，インターフェロン $-\alpha$ (以下， INF- $\alpha$ ) 治療目的にて当院泌尿器科に入院, 当科紹介となった.

所見 : 右中鼻道から総鼻道にかけて暗赤色表面不整で 凝血塊を伴う易出血性の腫瘤を認めた。 また, 右眼の視 力低下（裸眼視力にて $0.02 ）$ と眼球突出を認めた. 耳,
咽・喉頭，頸部には異常所見はみられなかった。

入院翌日, 右鼻腔の腫瘍から生検施行したところ, 病 理組織検查にて腎細胞癌の転移（腎淡明細胞癌 grade 2) と判明した。

病理組織所見：弱拡大像では全体的に赤血球を含んだ 血管が豊富にみられ，細胞質の明るい腫瘍細胞が全般に シート状に増殖している。一部乳頭状に配列していると ころがみられる(図 1 左)。

強拡大像でも細胞質の明るい腫瘍細胞の増殖がみら れ，一部核の大小不同や核形の不整がみられるが，ほと んどが円形あるいは楕円形で，全体的にやや大きい（図 1右).

また，摘出した腎の病理組織も同様の所見であり，腎 淡明細胞癌 grade 2 の副鼻腔転移と診断された.

副鼻腔造影 CT : 鼻腔，右上顎洞，右笠骨洞，一部右 蝶形骨洞, 眼窩を占める不均一に造影効果を受ける腫瘍 陰影を認める（図 2).

治療：肺転移や糖尿病，心筋梗塞などを考慮し，副鼻 腔の腫瘍に対しては手術適応なしと考え，右副鼻腔に外 照射を 1 日 $2 \mathrm{~Gy}$ を 25 回，総量で $50 \mathrm{~Gy}$ 施行した。 また， 

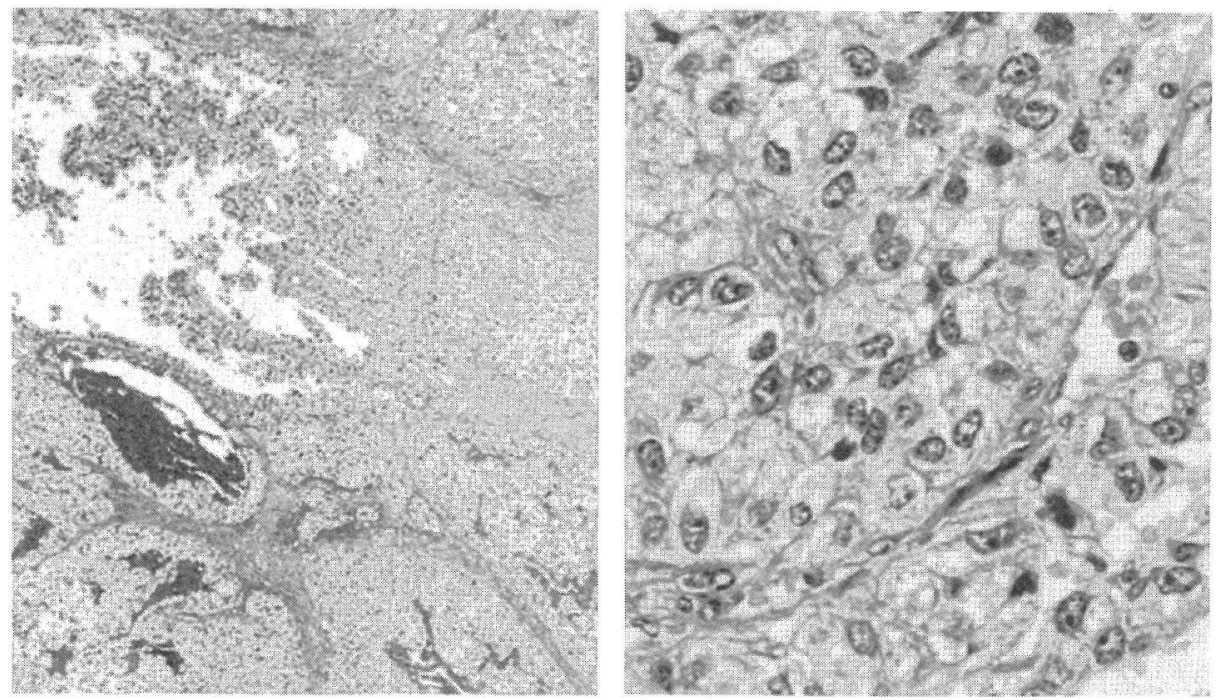

図 1 右副鼻腔腫瘍病理組織像 (HE 染色)

左：血管が豊富にみられ，腫瘍細胞が全般にシート状に増殖している $(\times 20)$.

右：細胞質の明るい腫瘍細胞の増殖がみられ，核形はほとんどが円形で，全体的にやや大 きい $(\times 400)$
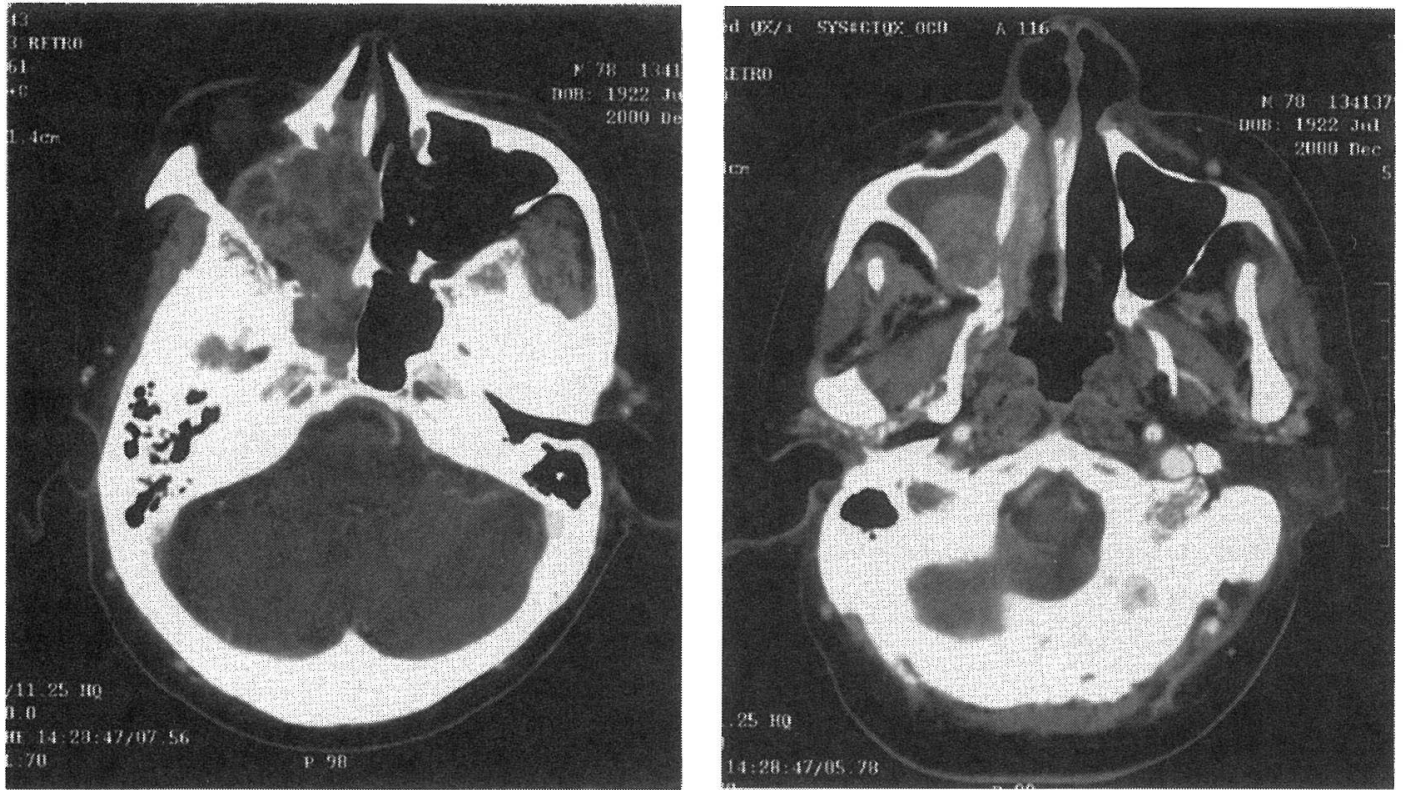

図 2 副鼻腔造影 CT 所見

鼻・副鼻腔を占める腫瘍性病変を認める.

左：右眼窩，蝶形骨洞へ進展している。

右：上顎洞後壁への浸潤がみられる。

肺転移に対する治療として泌尿器科にて INF- $\alpha$ の全身投 与を 300 万単位週 2 回施行した。

治療後副鼻腔造影 CT: 前回の CT と比ベて内部の造影
効果は低下しているが, 全体の大きさは増大している(図 3).

治療後所見 : 右眼窩への進展も増大し, 右視力は光覚 

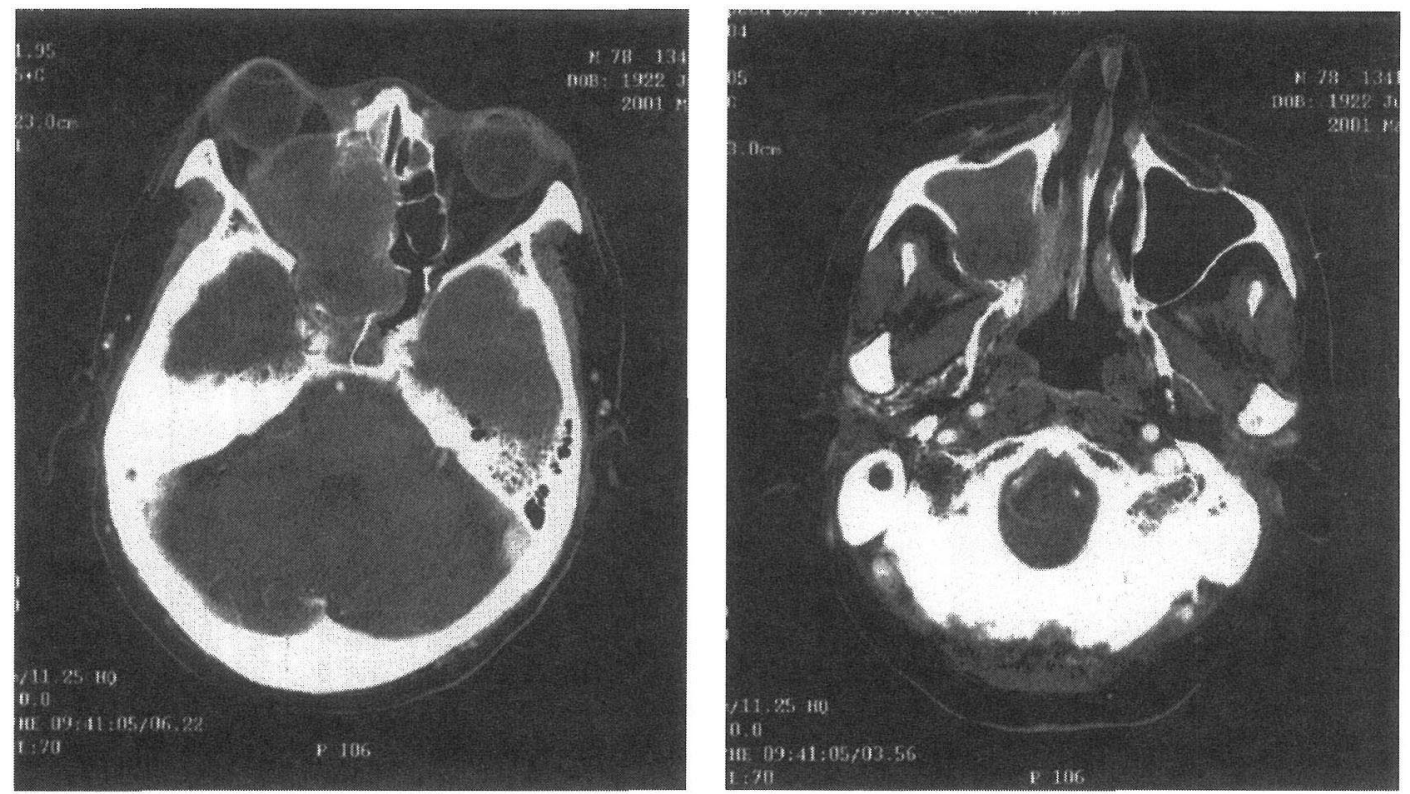

図 3 治療後副鼻腔造影 CT 所見 前回と比べ全体の大きさは増大している。 左：眼窝への進展が増大している. 右：上顎洞外への浸潤が増大している。

弁となり眼球突出む顕著になった。また，黄色の易出血 性の腫瘍が右中鼻道から総鼻道にかけて占拠していた。

その後当科外来にて経過観察しているが，緩徐ながら 副鼻腔腫瘍は増大傾向を示している。

\section{考察}

鼻・副鼻腔に他藏器からの転移性腫瘍が発生するのは きわめてまれである。過去の文献をみると, Bernstein ら11 は鼻・副鼻腔の転移性腫瘍 82 例を集計し, その原発巣と して腎が最も多く 40 例 (48.8\%)，次いで気管支・肺 10 例 $(12.2 \%)$ ，乳房 8 例 $(9.8 \%)$ の順と報告している. また，世良ら2）は22 例を報告し，原発巣として腎が最も 多く 12 例 $(54.5 \%)$, 次いで子宮 3 例 $(13.6 \%)$ ，大腸 2 例 $(9.1 \%)$ となっている。このことから，転移性副鼻腔 腫瘍のうち半数が腎癌の転移であるものといえる.

逆に，腎癌から頭頸部への転移の報告をみると，大越 ら3) は 409 例の腎癌の転移部位を剖検により詳細に調心゙ ているが，甲状腺 17 例（4.2\%）のみ記載されていた。 また，里見ら ${ }^{4)}$ は 124 例の腎癌を検討しているが，62 例 (50.0\%) に転移がみられ，そのうち頭頸部領域への転移 例は 4 例 $(3.2 \%)$ となっている。
次に腎癌の頭頸部転移例を集めた蔦ら ${ }^{5)}$ の報告をみる と，118 例のうち 50 例 (42.4\%) は副鼻腔への転移で, 次いで甲状腺が 27 例 (22.9\%)，耳下腺が 9 例 (7.6\%) である。

治療方法としては，転移の有無を問わず原発巣に対し て手術的摘除が有効加確実な治療法であり，生存期間 を有意に延長するという報告がある ${ }^{6)}$ 。単発の転移巣に 効しても，積極的に手術的摘除を行うのが効果的という 報告があり，また多発転移例に対しては INF- $\alpha$,インター ロイキン -2（IL-2）な巳゙の全身投与による免疫療法, 放 射線照射，化学療法などの補助的手段を考慮しなければ ならない7)。今回の症例では多発性肺転移，糖尿病，心 筋梗塞などの既往を考慮し，手術は行わず保存的治療の みとした。

\section{まとめ}

（1）副鼻腔に転移した腎癌の 1 例を報告した。

（2）副鼻腔転移性腫瘍は比較的まれであり原発巣とし ては腎癌が最も多い。

本論文の要旨は第 63 回日本耳鼻咽喉科学会静岡県地方部会 
(平成 13 年 4 月, 静岡市) において口演した.

\section{参考文献}

1) Bernstein JM, Montgomery WW, Balogh $K$, et al. : Metastatic tumors to the maxilla, nose and paranasal sinuses. Laryngoscope $76: 621 \sim 650,1966$.

2）世良公志, 夜陣紘治, 田頭宣治, 他 : 転移性上顎洞癌の一 例. 耳鼻臨床 補 $27: 89 \sim 96,1988$.

3）大越正秋, 長谷川昭: 腎腺癌の臨床病理学的統計. 日泌尿 会誌 $59: 1105 \sim 1116,1968$.

4）里見佳昭, 松浦謙一, 小川 英, 他 : 腎癌の耳鼻咽喉科領 域への転移症例. 臨泌 $28: 43 \sim 48,1974$.
5）蔦 佳尚, 井野千代徳, 山下敏夫, 他 : 腎細胞癌の耳下腺 転移の 1 例. 耳鼻 $36: 7 \sim 10,1990$.

6) Flanigan RC, Blumenstein BA, Salmon $\mathrm{S}$, et al. : Cytoreduction nephrectomy in metastatic renal cancer; the results of southwest Oncology Group trial 8949. Proc Am Soc Clin Oncol 19 : 2a, 2000 .

7）富田善彦：腎細胞癌有転移症例の治療. 臨泌 $54: 829 \sim$ 839,2000 .

原稿受付：平成13年 9 月 26 日

原稿採択 : 平成13年10月 31 日 急載 別刷請求先 : 大野恒久

厂 420-0853 静岡市追手町 10-93

静岡市立静岡病院耳鼻咽喉科 